Apidologie, 1987, 18 (4), 321-326

\title{
REPRODUCTION OF VARROA JACOBSONI DURING SUCCESSIVE BROOD CYCLES OF THE HONEYBEE
}

\author{
Arie de RUIJTER \\ Research Centre for Insect Pollination and Beekeeping "Ambrosiushoeve " \\ Ambrosiusweg 1, 5081 NG Hilvarenbeek, Netherlands
}

SUMMARY

Newly capped worker brood cells were numbered on a sheet of transparent plastic, temporarily attached to the top bar using two thumbtacks. Into each cell an adult female Varroa mite was introduced. After ten days the cells were opened and the contents studied. Those females still present and alive were introduced into newly capped brood cells an so on.

Varroa mites are capable of reproducing up to seven times this way. The maximum number of eggs laid was 30 per female. Females that produced male offspring only kept doing so in subsequent brood cycles. Though in contact with adult males several times, no successful mating had occurred. Probably only young females mate successfully.

\section{INTRODUCTION}

During the last few years substantial progress has been made in chemical control of Varroa jacobsoni (Ritrer et al., 1983 ; RITTER, 1986 ; de RUIJTER, 1986). However, most scientists working on Varroa control agree on the fact that more knowledge has to be gathered on the biology of the mite in order to develop biotechnical control methods (ARBeitsgemeinschaft, 1986). In this respect the reproduction of Varroa is of utmost importance.

Although sampling of Varroa-infested brood can give information concerning reproduction, more information can be gathered when mites are reared inside the colony, using the method developed by Ifantidis (Ifantidis, 1980).

The objectives of this study were to establish the maximum number of successive reproduction cycles and the maximum number of eggs laid by a single female. 


\section{MATERIALS AND METHODS}

Worker brood cells containing old larvae were marked on a sheet of transparent plastic, temporarily attached to the top bar, using two thumbtacks. The comb was put back into the colony and a few hours later the capped cells were numbered. From capped brood cells adult female mites, both " mothers » and "daughters", were collected. Into each newly capped cell one of these female Varroa mites was introduced by opening the cell carefully, letting the mite in and closing the cell thoroughly again.

After 10 days the cells were opened to examine the contents. Those females still present and alive were introduced into newly capped brood cells and so on.

\section{RESULTS AND DISCUSSION}

In 315 cells the female mite was regained alive, 250 with offspring, 65 without offspring $(20.7 \%)$. If there is no offspring, this does not always mean that the mite is infertile. Twenty one mites interrupted egg laying for one period or more and resumed egg laying in the next period. This may be due to the lack of stimulus, perhaps a result of the haemolymph composition of the pupa. Six mites did not lay eggs at all. The percentage of mites without offspring may be an important criterion for selecting Varroa-resistant bees. It should be kept in mind however, that the first time mites are introduced this percentage may be slightly higher than later on, because very young mites do not lay eggs during the first period.

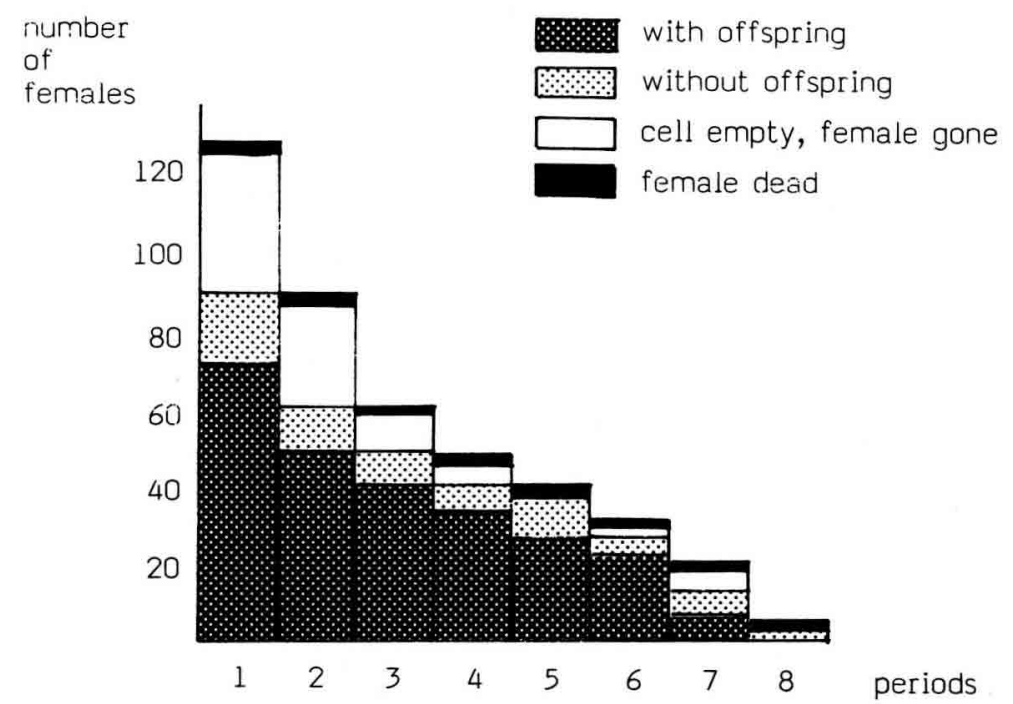

Fig. 1. - Reproduction of Varroa jacobsoni in honey bee cells during - successive periods of 10 days each 
Figure 1 shows the reproduction in 8 successive periods of 10 days each. Offspring were found in 7 periods. Only a few mites were found to be dead. Most of the mites disappeared because the bees refused the cells we opened and did not close completely again. The bees uncapped these celles and cleaned them out.

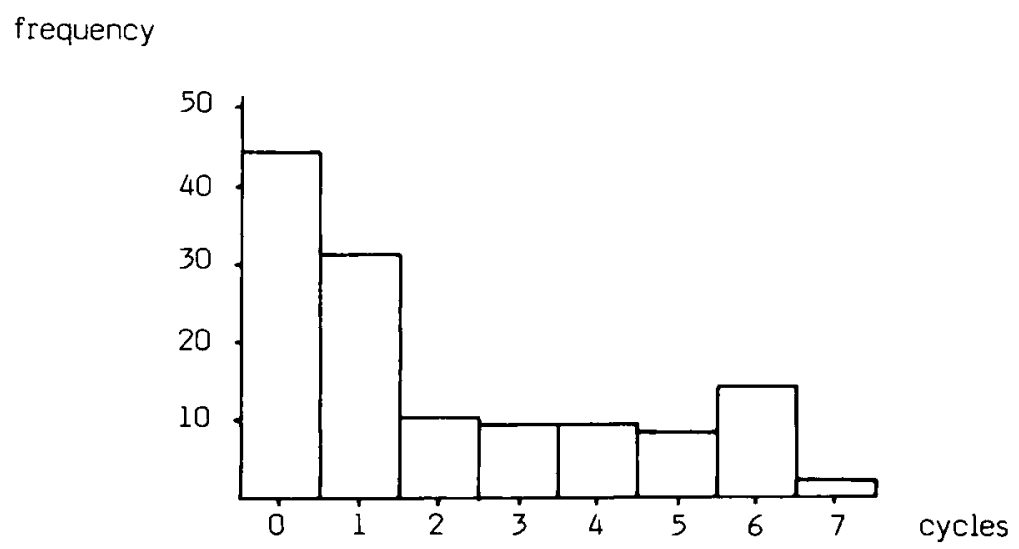

FIG. 2. - Frequency of the number of successful reproduction cycles of Varroa jacobsoni. All females

frequency

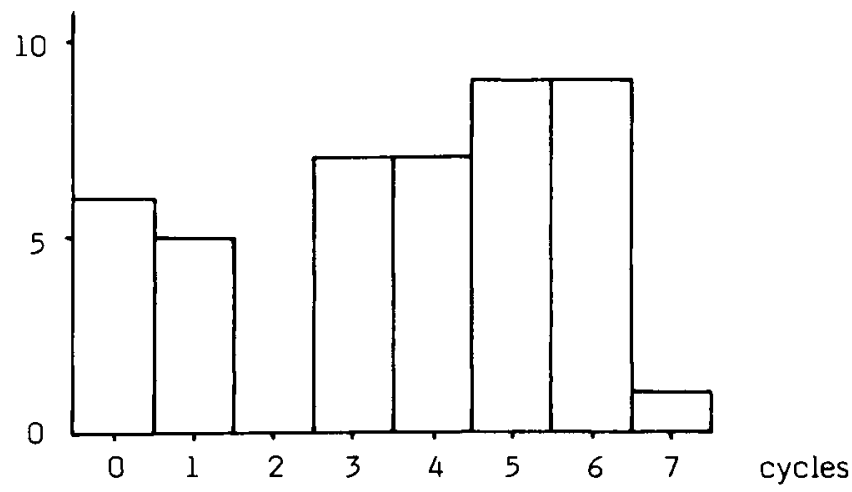

Fig. 3. - Frequency of the number of successful reproduction cycles of Varroa jacobsoni, not including females that were lost 
mean number of eggs per period
- offspring of both sexes

$\Delta$ male offspring only

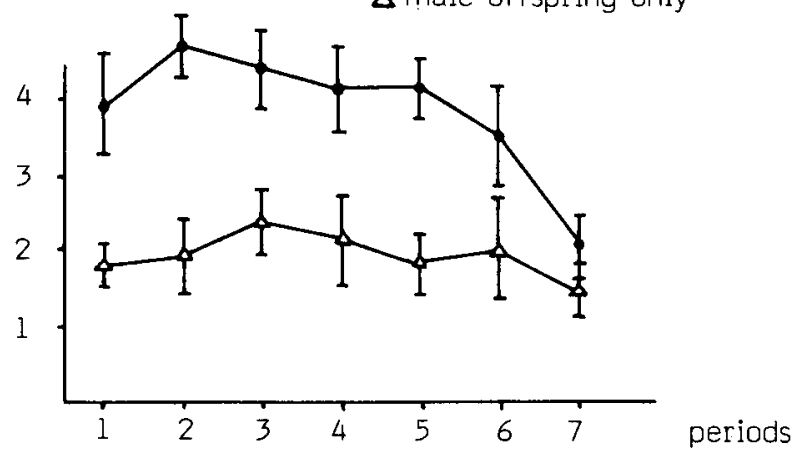

Fig. 4. - Mean number of Varroa jacobsoni eggs per period from females with offspring in 4 periods or more

total number of eggs per female

30

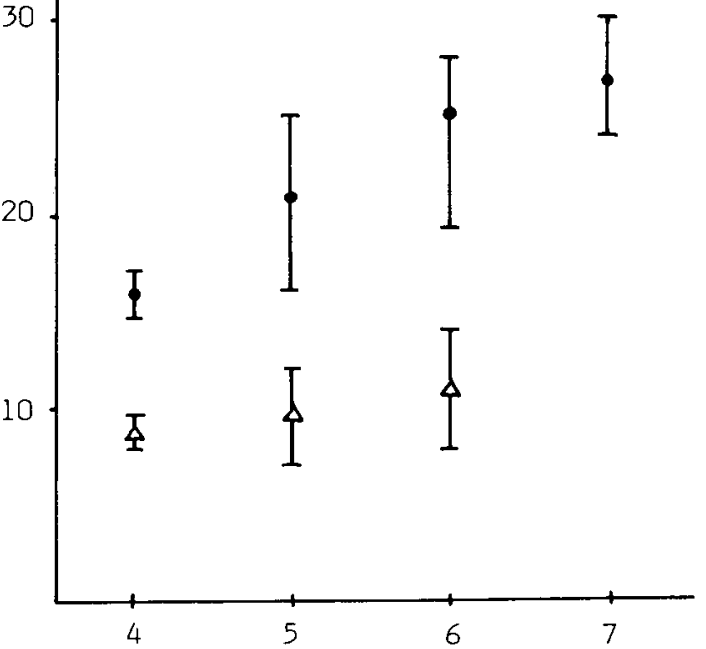

- offspring of both sexes

$\Delta$ male offspring only periods

Fig. 5. - Total number of Varroa jacobsoni eggs per female (maximum, mean and minimum)

The frequency of the number of successful reproductive cycles is shown in Fig. 2. Zero or one successful cycle were the most frequent. Two, 3, 4, 5 or 6 cycles occurred also and the maximum was 7 cycles with offspring. If we exclude the mites that were lost, due to the method, and only look at the 
mites that were found dead or were regained alive, 5 or 6 successful cycles were most frequent (Fig. 3). To determine if there was a decrease in the number of eggs laid in successive periods, we selected those mites that had offspring in 4 periods or more. When offspring of both sexes occurred (Fig. 4), the number of eggs per period was about 4 , with a slight decrease until the sixth period and then dropped to 2 eggs. In those cases where females were unmated and had male offspring only, the average number of eggs was 2 per period. The total number of eggs laid per individual female increased with the number of successful periods (Fig. 5). The maximum number of eggs laid by unmated females was much smaller. Females that produced male offspring only kept doing so in subsequent brood cycled. Though in contact with adult males several times, no successful mating had occurred. Probably only young females mate successfully.

\title{
CONCLUSION
}

Varroa mites are able to reproduce up to seven times and are capable of producing up to 30 eggs. Contact with adult bees is not indispensable for reproduction. In spite of our manipulating these mites, some of them lived over 2.5 months in summer.

Whether this maximum reproduction is reached in nature depends on different factors inside the bee colony, of which we have only limited knowledge.

Received for publication in November 1986. Accepted for publication in March 1987.

\author{
RÉSUMÉ \\ REPRODUCTION DE VARROA JACOBSONI \\ AU COURS DE CYCLES SUCCESSIFS DE COUVAIN CHEZ L'ABEILLE
}

On a numéroté des cellules récemment operculées de couvain d'ouvrières sur 1 feuille de plastique transparent, attaché momentanément à la baguette supéricure par 2 punaises. On a introduit dans chaque cellule une femelle adulte de Varroa. Au bout de 10 jours on a ouvert les cellules et étudić lcur contenu. Les femelles encore présentes et vivantes ont été introduites dans des cellules de couvain nouvellement operculées et ainsi de suite.

Les acariens Varroa peuvent se reproduire de cette manière jusqu'à 7 fois (Fig. 1-5). Le nombre maximum d'cufs pondus a été de 30 par femelle. Les femelles qui n'ont donné que des descendants mâles ont continué de la même façon pendant les cycles suivants. Bien qu'en contact avec des mâles à plusicurs reprises, aucune femelle n'a réussi à s'accoupler. Vraiscmblablement seules les femelles jeunes parviennent à s'accoupler. 


\section{ZUSAMMENFASSUNG}

\section{FORTPFLANZUNG VON VARROA-MILBEN \\ WÄHREND AUFEINANDERFOLGENDER BRUTZYKLEN DER HONIGBIENE}

Frisch verdeckelte Arbeiter-Brutzellen wurden mit einer durchsichtigen, am Rähmchenoberträger mit Reißnägeln befestigten Plastikfolie überdeckt und einzeln numeriert. In jede Zelle wurde eine VarroaMilbe eingesetzt. Nach 10 Tagen wurden die Zellen zur Untersuchung des Inhalts geöffnet. Milbenweibehen, die noch vorhanden und am Leben waren, wurden in frisch verdeckelte Brutzellen übertragen, und so fort.

Bei diesem Verfahren können sich Varroaweibchen bis zu siebenmal hintereinander fortpflanzen (Abb. 1-5). Die höchste Zahl der von einem Weibchen abgelegten Eier war 30. Weibchen, die nur männliche Nachkommen erzeugten, verhielten sich in den folgenden Brutzyklen ebenso. Obwohl sie mehrmals mit erwachsenen Männchen Kontakt hatten, war offensichtlich keine wirkungsvolle Paarung erfolgt. Wahrscheinlich können sich nur junge Weibchen erfolgreich paaren.

\section{REFERENCE}

Arbeitsgemeinschaft der Institute für Bienenforschung, 1986. - Empfehlungen zur praxisorientierten Varroatose-Forschung. Allg. dtsch. Imkerztg., 20 (9), 288.

IfaNtIDIs M.D., 1980. - Ontogenesis of the mite Varroa jacobsoni O. in the worker and drone brood cell of the honey bee Apis mellifera cecropia. J. Apic. Res., 22 (3), 200-206.

Ritrer W., Perschil F., Czarnecki J.M., 1983. - Treatment of bee colonies with isopropyl-4,4dibromo-benzilate against Varroa disease and Acarine disease. Zentralbl. Vet. Med. B, 30, 266-273.

Ritrer W., 1986. - Die Varroatose der Honigbiene, Apis mellifera, und ihre Bekämpfung mit Perizin. Vet. med. Nachr., (1), 3-16.

Ruijter A. de, Eujnde J. van den, 1986. - Field experiment to determine the effects of Perizin on Varroa mites and on development of treated colonies. Vet. med. Rev., (2), 158-163. 